\title{
MALACOCOENOSES OF FRAGMENTED FORESTS OF WIELKOPOLSKA
}

\author{
ELŻBIETA KORALEWSKA-BATURA ${ }^{1}$, JERZY BŁOSZYK ${ }^{2,3}$, AGNIESZKA NAPIERAŁA ${ }^{2}$ \\ ${ }^{1}$ Department of General Zoology, Adam Mickiewicz University, Fredry 10, 61-701 Poznań, Poland \\ ${ }^{2}$ Department of Animal Ecology and Taxonomy, Adam Mickiewicz University, Umultowska 89, \\ 61-614 Poznań, Poland \\ ${ }^{3}$ Natural History Collections, Faculty of Biology, Adam Mickiewicz University, Umultowska 89, \\ 61-614 Poznań, Poland
}

\begin{abstract}
Terrestrial malacocoenoses of two neighboring forest complexes in W. Wielkopolska were sampled in 2003-2004; their structure and abundance were analysed in selected plots of oak-hornbeam forest of different protection status and degree of anthropogenic transformations. Twenty species (10 families) represented by 1,588 specimens were collected. The main components of the malacocoenoses were: Nesovitrea hammonis, Aegopinella nitidula, Ae. pura, Punctum pygmaeum, Cochlicopa lubricella, Perforatella incarnata and Carychium minimum. Both species composition and abundance varied greatly between the plots. The gastropods showed no preference for old oak-hornbeam stands or plots located in nature reserves. This may suggest that even under strong anthropopressure and in much transformed environments the snails are capable of maintaining a high diversity.
\end{abstract}

KEY WORDS: terrestrial gastropods, malacocoenosis, forests, community structure, diversity

\section{INTRODUCTION}

The agricultural development of the Wielkopolska region in the past has resulted in most forest areas, especially rich oak-hornbeam stands, being replaced with cultivated fields. The remaining forests have been divided into small, isolated fragments, scattered among fields and meadows. The situation is reflected by changes in the structure of various invertebrate communities. The decrease in the forested areas results not only in shrinking of available space and food basis, but also in isolation of local populations which may disturb their normal functioning. This pertains especially to species of limited dispersal potential, among others terrestrial gastropods.

\section{STUDY AREA}

The study plots were located in two isolated forest complexes of different surface area (Fig. 1). The forest complex near Duszniki $\left(1 \mathrm{~km}^{2}\right)$ is located ca. 30
Earlier malacological studies in the area were of faunistic character (KORALEWSKA-BATURA 1989, 1992, 1993a, b, JANKOWIAK et al. 1991) and only to a slight extent considered seasonal changes in malacocoenoses. The main objective of this study was to trace, over a year, the functioning of malacocoenoses of two neighboring but isolated forest complexes with a different degree of anthropopressure, as well as changes in the species composition and community structure, depending on the kind of vegetation.

km north of Poznań (UTM: WU 91). Five neighboring plots of different soil structure, vegetation cover and age of tree stands were selected there. Originally 


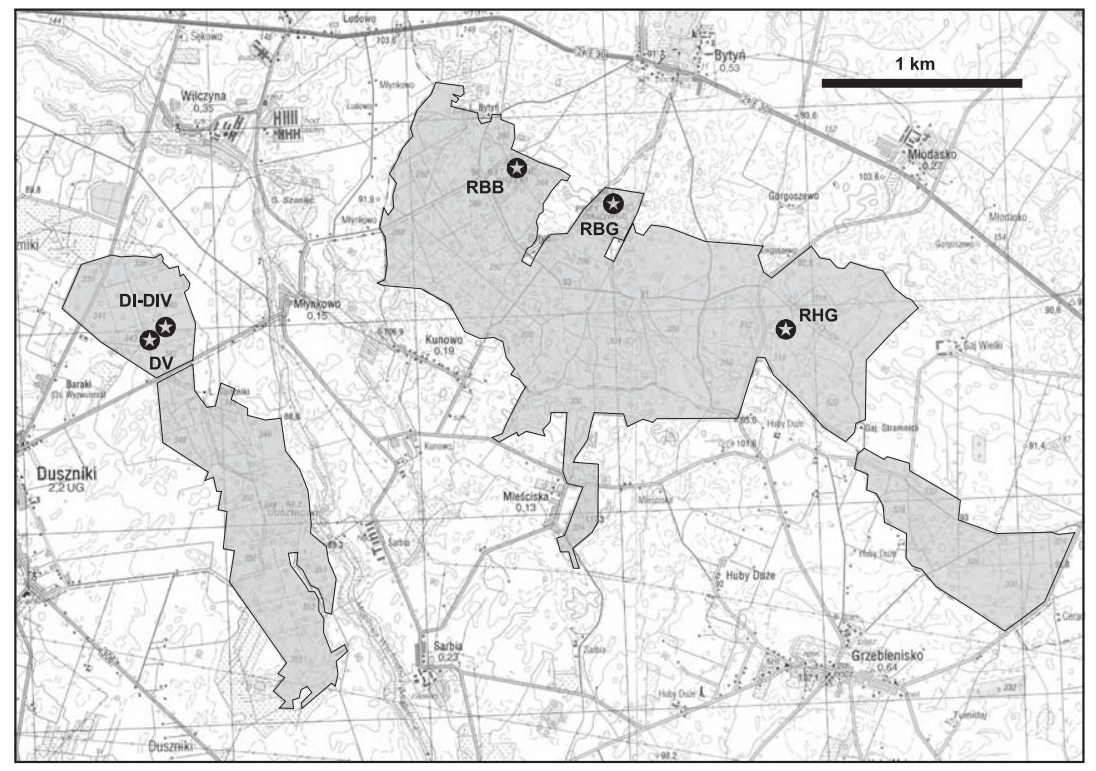

Fig. 1. Location of the study plots in two forest complexes of W. Wielkopolska: DIDV - plots in the forest near Duszniki; RBB - nature reserve "Bytyńskie Brzęki", RBG - nature reserve "Brzęki przy Starej Gajówce", RHG - nature reserve "Huby Grzebieniskie" they were components of a uniform oak-hornbeam forest with an admixture of larch; the forest was transformed as a result of partial clear-felling. Individual plots represented different degrees of anthropogenic transformations. Two plots, further referred to as D-I and D-II, were located in an old tree stand $(>120$ years), and D-II additionally contained an admixture of larch. The third plot (D-III) was a hornbeam forest of ca. 60 years, with a slight admixture of oak, which had grown on a clear-felled area. Plots D-IV and D-V were clear-felled areas ca. 20 years old, where oak had been planted immediately after clear-felling. The nursery failed and in both cases natural succession took place: in D-IV expansion of hazel and birch, in $\mathrm{D}-\mathrm{V}$ - ash, resulting in an ash-elm riverine forest.
The second forest complex $\left(2.4 \mathrm{~km}^{2}\right)$ included three plots. They corresponded to two forest nature reserves: "Bytyńskie Brzęki" (RBB) and "Brzęki przy Starej Gajówce” (RBG) (UTM: WU 91), and a floristic reserve "Huby Grzebieniskie" (RHG) (UTM: XU 01), located ca. $25 \mathrm{~km}$ west of Poznan. The RBB protects an oak-hornbeam forest with a rich stand of the rowan Sorbus torminalis. The aim of the RBG is to protect, for scientific and educational reasons, a fragment of mixed forest with one of the largest stands of Sorbus torminalis in Wielkopolska. The RHG was established in order to preserve some fragments of a deciduous forest with the only locality of Cypripedium calceolus in Wielkopolska.

\section{MATERIAL AND METHODS}

Samples were taken monthly in eight plots, from May 2003 till April 2004, with Oekland frame of $25 \times$ $25 \mathrm{~cm}$. Each month on each plot eight unit samples were taken randomly, to a total area of $0.5 \mathrm{~m}^{2}$. The total number of unit samples during the year was 768 . They contained 1,588 specimens representing 20 species of 10 families (Table 1 ). The nomenclature and classification follow WIKTOR (2004). The data analy- sis included the following ecological indices: dominance (D), constancy of occurrence (C), density, Shannon-Weaver diversity index (H'), similarity index of Marczewski and Steinhaus, and cluster analysis of malacocoenoses (MARCZEWSKI \& STEINHAUS 1959, GÓRNY \& GRÜM 1993). Dominance and constancy classes were adopted after BŁOSZYK (1999).

\section{RESULTS}

\section{ZOOCOENOLOGICAL ANALYSIS}

The material served as a basis for proposing a structure of a hypothetical malacocoenosis of the forest floor of studied forests for that part of Wielkopolska (Table 2). The abundance of particular species varied rather widely and ranged from 16 to 912 indiv. $\mathrm{m}^{-2}$. Nesovitrea hammonis was abundant and frequent in the studied forests; it constituted 1/3 malacocoenosis and its contancy exceeded 20\%. Its density ranged from 16 to 256 indiv. $\mathrm{m}^{-2}$. With respect to abundance it was followed by five species: Columella edentula (12.3\%), 
Table 1. Species composition of the studied malacoocenoses: RBB - nature reserve "Bytyńskie Brzęki"; RBG - nature reserve "Brzęki przy Starej Gajówce"; RHG - nature reserve "Huby Grzebieniskie"; D - investigated plots in Duszniki forest complex

\begin{tabular}{|c|c|c|c|c|c|c|c|c|c|}
\hline \multirow{2}{*}{ No. } & \multirow{2}{*}{ Species } & \multicolumn{8}{|c|}{ Site } \\
\hline & & RBB & RBG & RHG & D-I & D-II & D-III & D-IV & $\mathrm{D}-\mathrm{V}$ \\
\hline 1 & Carychium minimum O. F. Müller, 1774 & + & & & & & & & + \\
\hline 2 & Succinea oblonga O. F. Müller, 1774 & + & & & & & & & \\
\hline 3 & Cochlicopa lubrica (O. F. Müller, 1774) & + & + & + & & & & & \\
\hline 4 & Cochlicopa lubricella (Porro, 1838) & + & + & + & & + & & + & + \\
\hline 5 & Columella edentula (Draparnaud, 1805) & & & & & + & & + & + \\
\hline 6 & Vertigo pusilla O. F. Müller, 1774 & & & & & & & & + \\
\hline 7 & Vertigo substriata (Jeffreys, 1833) & + & & & & & & & + \\
\hline 8 & Vallonia costata (O. F. Müller, 1774) & & & & & & & & + \\
\hline 9 & Vallonia pulchella (O. F. Müller, 1774) & & & & & & & & + \\
\hline 10 & Acanthinula aculeata (O. F. Müller, 1774) & + & & & & & & & + \\
\hline 11 & Punctum pygmaeum (Draparnaud, 1801) & + & & & & + & & + & + \\
\hline 12 & Arion subfuscus (Draparnaud, 1805) & & & & & & & & + \\
\hline 13 & Vitrea crystallina (O. F. Müller, 1774) & + & & + & & & & & + \\
\hline 14 & Aegopinella nitidula (Draparnaud, 1805) & + & + & + & + & + & & + & + \\
\hline 15 & Aegopinella pura (Alder, 1830) & + & + & + & + & + & & + & + \\
\hline 16 & Nesovitrea hammonis (Ström, 1765) & + & + & + & + & + & + & + & + \\
\hline 17 & Euconulus fulvus (O. F. Müller, 1774) & + & + & & & + & & + & + \\
\hline 18 & Perforatella incarnata (O. F. Müller, 1774) & & & + & + & + & & + & + \\
\hline 19 & Euomphalia strigella (Draparnaud, 1801) & & & + & & & & + & + \\
\hline 20 & Cepaea hortensis (O. F. Müller, 1774) & & & & & & & & + \\
\hline & Total species: & 12 & 6 & 8 & 4 & 8 & 1 & 9 & 18 \\
\hline
\end{tabular}

Cochlicopa lubricella (10.3\%), Vallonia costata (9.3\%), Carychium minimum $(8.0 \%)$ and Punctum pygmaeum $(5.3 \%)$, were much less frequent and their constancy did not exceed $7 \%$. The remaining species were accidental, and placed in low dominance classes (Table 2).

\section{SEASONAL CHANGES IN THE SPECIES COMPOSITION AND STRUCTURE}

Samples taken in annual cycle made it possible to trace seasonal changes in the species number and abundance of malacocoenoses and individual species. The number of species usually ranged from 11 to 15 . Only in the first month of the studies (May 2003) the number of species was seven, and in March 2004-18. The total abundance showed two peaks: in summer (maximum in July) and in winter (maximum in January) (Fig. 2). The only departure from this cycle was the number of snails in March 2004 - twice higher than in any of the remaining months.

The seasonal differences in the number of species and individuals were similar in phytosociologically different plots of the forest complex near Duszniki (Figs 3, 4), but further, long-term observations are necessary to reveal any regularities.
Table 2. Dominance and constancy structure of the hypothetical malacocoenosis

\begin{tabular}{cc}
\hline \multicolumn{1}{c}{ Dominance $(\mathrm{D} \%)$} & Constancy $(\mathrm{C} \%)$ \\
\hline $\mathrm{D}_{5}$ Eudominants & $\mathrm{C}_{5}$ Euconstants \\
Nesovitrea hammonis 33.2 & absent \\
$\mathrm{D}_{4}$ Dominants & $\mathrm{C}_{4}$ Constants \\
absent & absent \\
$\mathrm{D}_{3}$ Subdominants & $\mathrm{C}_{3}$ Subconstants \\
Columella edentula 12.3 & Nesovitrea hammonis 23.2 \\
Cochlicopa lubricella 10.3 & \\
Vallonia costata 9.3 & \\
Carychium minimum 8.0 & \\
$\mathrm{D}_{2}$ Recedents & \\
Punctum pygmaeum 5.3 & $\mathrm{C}_{2}$ Accessory species \\
Aegopinella nitidula 3.3 & Cochlicopa lubricella 6.9 \\
& Columella edentula 5.2 \\
$\mathrm{D}_{1}$ Subrecedents & Vallonia costata 5.1 \\
13 species & $\mathrm{C}_{1}$ Accidental species \\
\hline
\end{tabular}




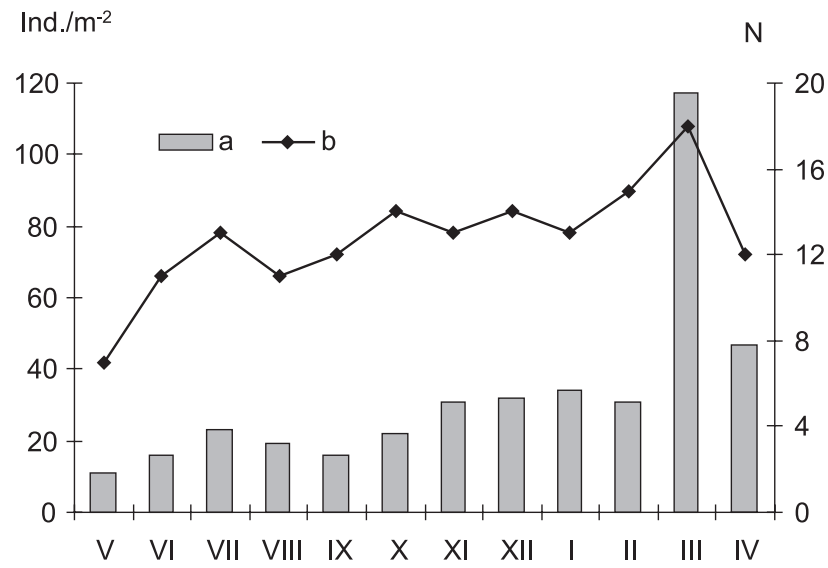

Fig. 2. Mean density (a) and the number of species (b) in the studied malacocoenoses in consecutive months of 2003-2004

Only two of the 20 species recorded occurred regularly throughout the year (Table 3): Nesovitrea hammonis and Cochlicopa lubricella. Another three species, i.e. Aegopinella nitidula, Vallonia costata and Aegopinella pura were present in samples from 11 months.

\section{A}

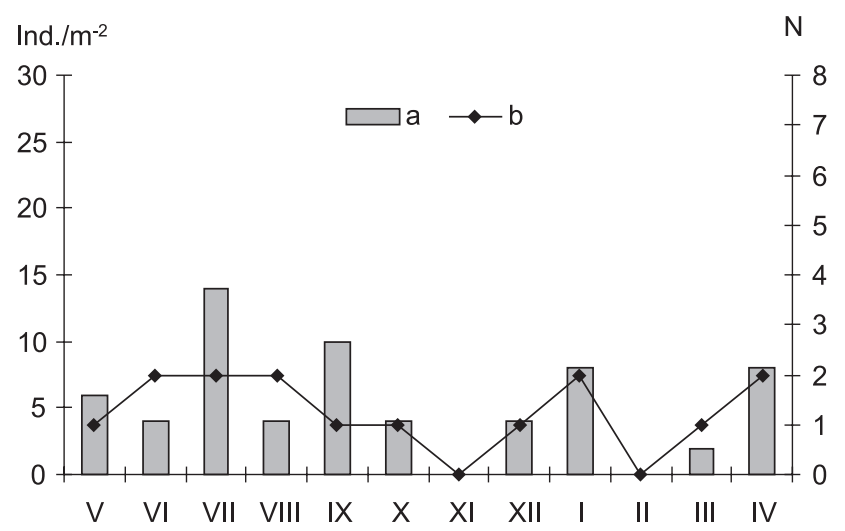

C

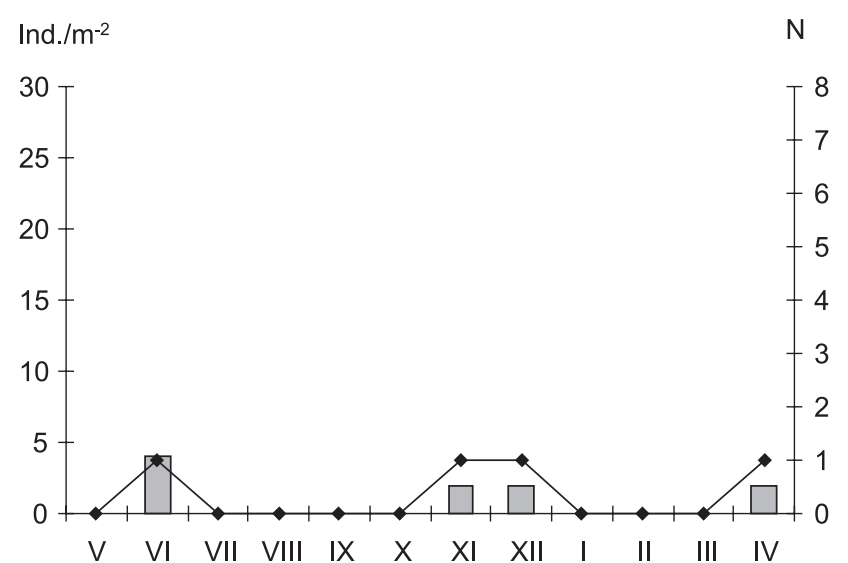

The remaining species were either irregular, or their occurrence was limited to particular periods.

\section{THE EFFECT OF PROTECTION STATUS OF THE FOREST ON THE MALACOCOENOSES}

Three of the plots were located in nature reserves which have existed since 1959; the remaining five were situated in a managed, economically exploited forest near Duszniki. The 288 unit samples from the protected area contained 14 snail species; the respective numbers for non-protected plots were 480 and 18 (Table 4).

Twelve species were common for the two types of plots; two were found exclusively in the nature reserves (Succinea oblonga and Cochlicopa lubrica), and six only in non-protected areas (Columella edentula, Vertigo pusilla, Vallonia costata, V. pulchella, Arion subfuscus and Cepaea hortensis); the similarity in species composition (S) was $60 \%$. In both cases the most abundant and the most frequent species was $N$. hammonis, forming a similar proportion in the samples from protected and non-protected plots.

\section{B}

Ind. $/ \mathrm{m}^{-2} \quad \mathrm{~N}$

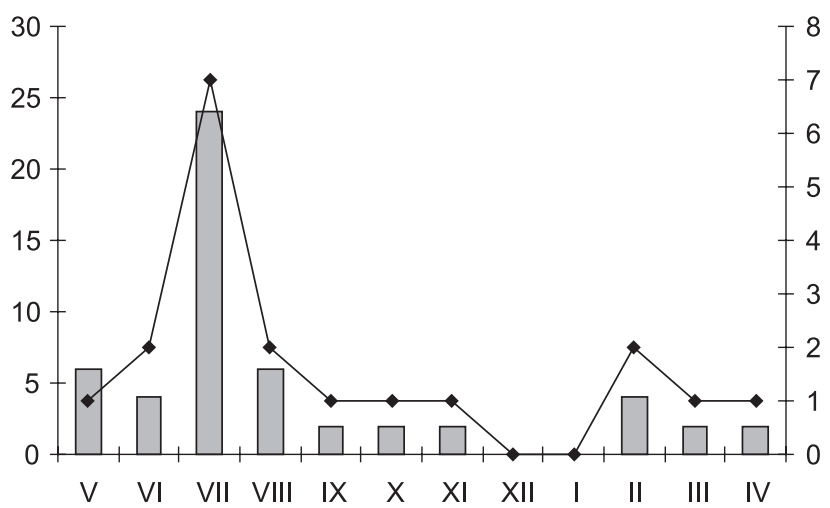

\section{D}

Ind. $/ \mathrm{m}^{-2}$

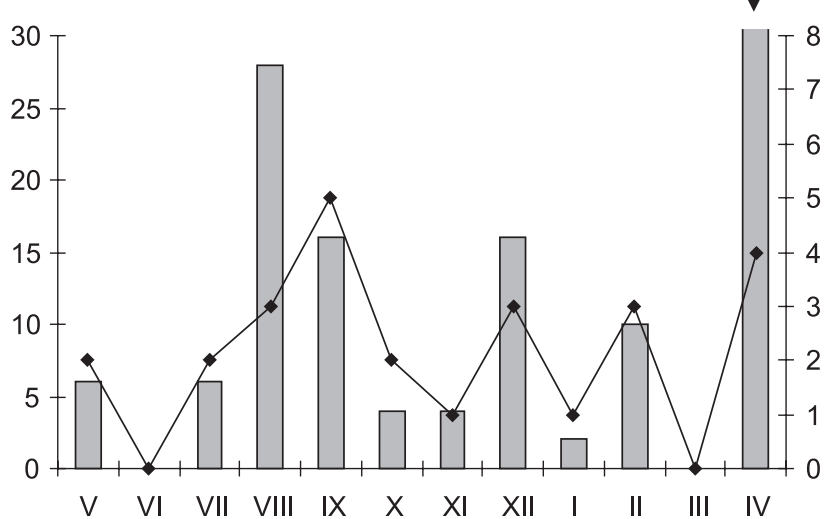

Fig. 3. Mean density (a) and the number of species (b) in consecutive months in 2003-2004 in study plots in the forest near Duszniki: A - old oak-hornbeam forest (D-I); B - old oak-hornbeam forest with admixture of larch (D-II); C - young oak-hornbeam forest (D-III); D - clear-felled plot (D-IV) 


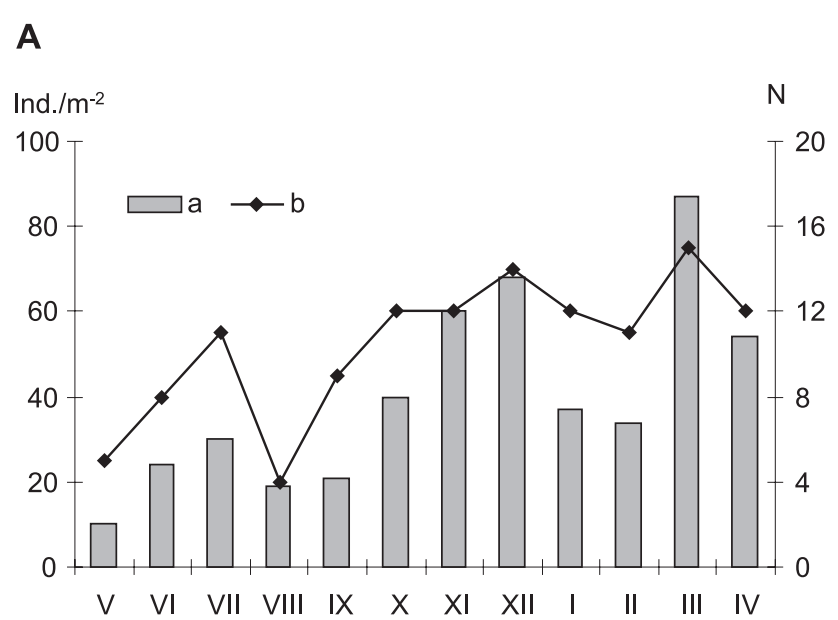

\section{B}

Ind. $/ \mathrm{m}^{-2} \quad \mathrm{~N}$

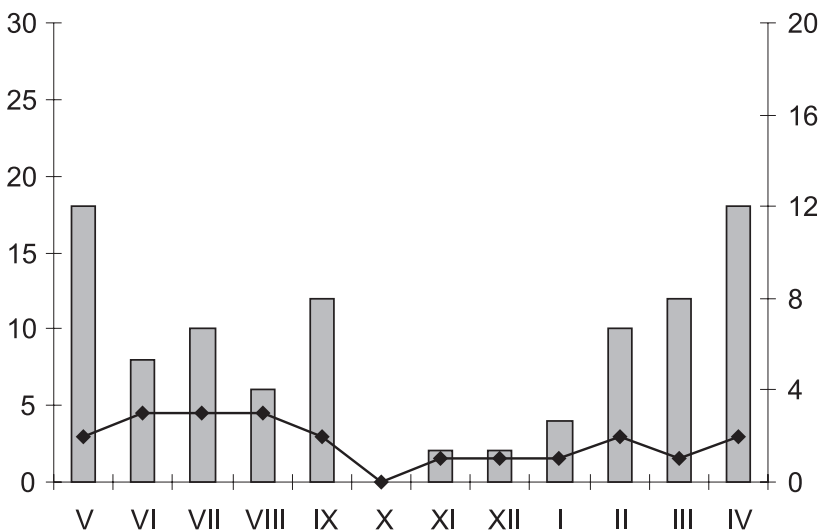

C

D
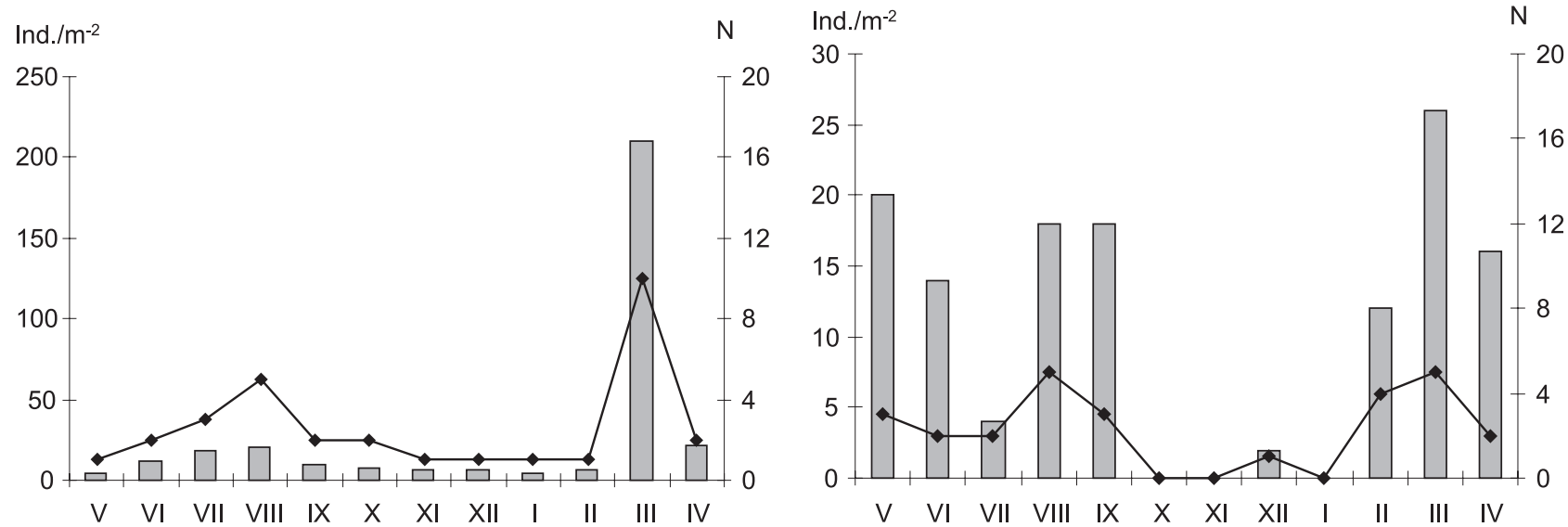

Fig. 4. Mean density (a) and the number of species (b) in consecutive months in 2003-2004 in: A - ash-elm riverine forest near Duszniki (D-I); B - nature reserve "Bytyńskie Brzęki" (RBB); C - nature reserve "Brzęki przy Starej Gajówce" (RBG); D - nature reserve "Huby Grzbieniskie" (RHG)

Table 3. Occurrence of component species of the studied malacocoenoses in consecutive months of 2003-2004

\begin{tabular}{|c|c|c|c|c|c|c|c|c|c|c|c|c|}
\hline Species/month & $\mathrm{V}$ & VI & VII & VIII & IX & $\mathrm{X}$ & XI & XII & I & II & III & IV \\
\hline Nesovitrea hammonis & $\mathrm{X}$ & $\mathrm{X}$ & $\mathrm{X}$ & $\mathrm{X}$ & $\mathrm{X}$ & $\mathrm{X}$ & $\mathrm{X}$ & $\mathrm{X}$ & $\mathrm{X}$ & $\mathrm{X}$ & $\mathrm{X}$ & $\mathrm{X}$ \\
\hline Cochlicopa lubricella & $\mathrm{X}$ & $\mathrm{X}$ & $\mathrm{X}$ & $\mathrm{X}$ & $\mathrm{X}$ & $\mathrm{X}$ & $\mathrm{X}$ & $\mathrm{X}$ & $\mathrm{X}$ & $\mathrm{X}$ & $\mathrm{X}$ & $\mathrm{X}$ \\
\hline Aegopinella nitidula & $\mathrm{X}$ & $\mathrm{X}$ & $\mathrm{X}$ & $\mathrm{X}$ & $\mathrm{X}$ & $\mathrm{X}$ & $\mathrm{X}$ & $\mathrm{X}$ & $\mathrm{X}$ & $\mathrm{X}$ & $\mathrm{X}$ & \\
\hline Vallonia costata & & $\mathrm{X}$ & $\mathrm{X}$ & $\mathrm{X}$ & $\mathrm{X}$ & $\mathrm{X}$ & $\mathrm{X}$ & $\mathrm{X}$ & $\mathrm{X}$ & $\mathrm{X}$ & $\mathrm{X}$ & $\mathrm{X}$ \\
\hline Aegopinella pura & & $\mathrm{X}$ & $\mathrm{X}$ & $\mathrm{X}$ & $\mathrm{X}$ & $\mathrm{X}$ & $\mathrm{X}$ & $\mathrm{X}$ & $\mathrm{X}$ & $\mathrm{X}$ & $\mathrm{X}$ & $\mathrm{X}$ \\
\hline Columella edentula & & & $\mathrm{X}$ & & $\mathrm{X}$ & & $\mathrm{X}$ & $\mathrm{X}$ & $\mathrm{X}$ & $\mathrm{X}$ & $\mathrm{X}$ & $\mathrm{X}$ \\
\hline Carychium minimum & & $\mathrm{X}$ & & & $\mathrm{X}$ & $\mathrm{X}$ & $\mathrm{X}$ & $\mathrm{X}$ & & $\mathrm{X}$ & $\mathrm{X}$ & $\mathrm{X}$ \\
\hline Perforatella incarnata & & $\mathrm{X}$ & $\mathrm{X}$ & $\mathrm{X}$ & $\mathrm{X}$ & $\mathrm{X}$ & $\mathrm{X}$ & & $\mathrm{X}$ & $\mathrm{X}$ & $\mathrm{X}$ & \\
\hline Punctum pygmaeum & & & $\mathrm{X}$ & & $\mathrm{X}$ & $\mathrm{X}$ & $\mathrm{X}$ & $\mathrm{X}$ & $\mathrm{X}$ & $\mathrm{X}$ & $\mathrm{X}$ & $\mathrm{X}$ \\
\hline Vertigo pusilla & & & $\mathrm{X}$ & & $\mathrm{X}$ & $\mathrm{X}$ & $\mathrm{X}$ & $\mathrm{X}$ & $\mathrm{X}$ & $\mathrm{X}$ & $\mathrm{X}$ & $\mathrm{X}$ \\
\hline Cochlicopa lubrica & $\mathrm{X}$ & $\mathrm{X}$ & $\mathrm{X}$ & $\mathrm{X}$ & $\mathrm{X}$ & & & & & $\mathrm{X}$ & $\mathrm{X}$ & \\
\hline Euconulus fulvus & & $\mathrm{X}$ & $\mathrm{X}$ & & $\mathrm{X}$ & $\mathrm{X}$ & $\mathrm{X}$ & $\mathrm{X}$ & & & $\mathrm{X}$ & \\
\hline Euomphalia strigella & & $\mathrm{X}$ & & $\mathrm{X}$ & $\mathrm{X}$ & $\mathrm{X}$ & & $\mathrm{X}$ & & $\mathrm{X}$ & $\mathrm{X}$ & \\
\hline Vertigo substriata & & & & $\mathrm{X}$ & & & $\mathrm{X}$ & $\mathrm{X}$ & $\mathrm{X}$ & $\mathrm{X}$ & $\mathrm{X}$ & $\mathrm{X}$ \\
\hline Acanthinula aculeata & & & $\mathrm{X}$ & $\mathrm{X}$ & & & & & $\mathrm{X}$ & & $\mathrm{X}$ & $\mathrm{X}$ \\
\hline Vitrea crystallina & $\mathrm{X}$ & & & $\mathrm{X}$ & & & $\mathrm{X}$ & & & & $\mathrm{X}$ & \\
\hline Cepaea hortensis & & $\mathrm{X}$ & & & & & & & $\mathrm{X}$ & & & $\mathrm{X}$ \\
\hline Vallonia pulchella & & & & & $\mathrm{X}$ & & & & & $\mathrm{X}$ & & \\
\hline Succinea oblonga & & $\mathrm{X}$ & & $\mathrm{X}$ & & & & & & & & \\
\hline Arion subfuscus & $\mathrm{X}$ & & & & & & & & & & & \\
\hline
\end{tabular}




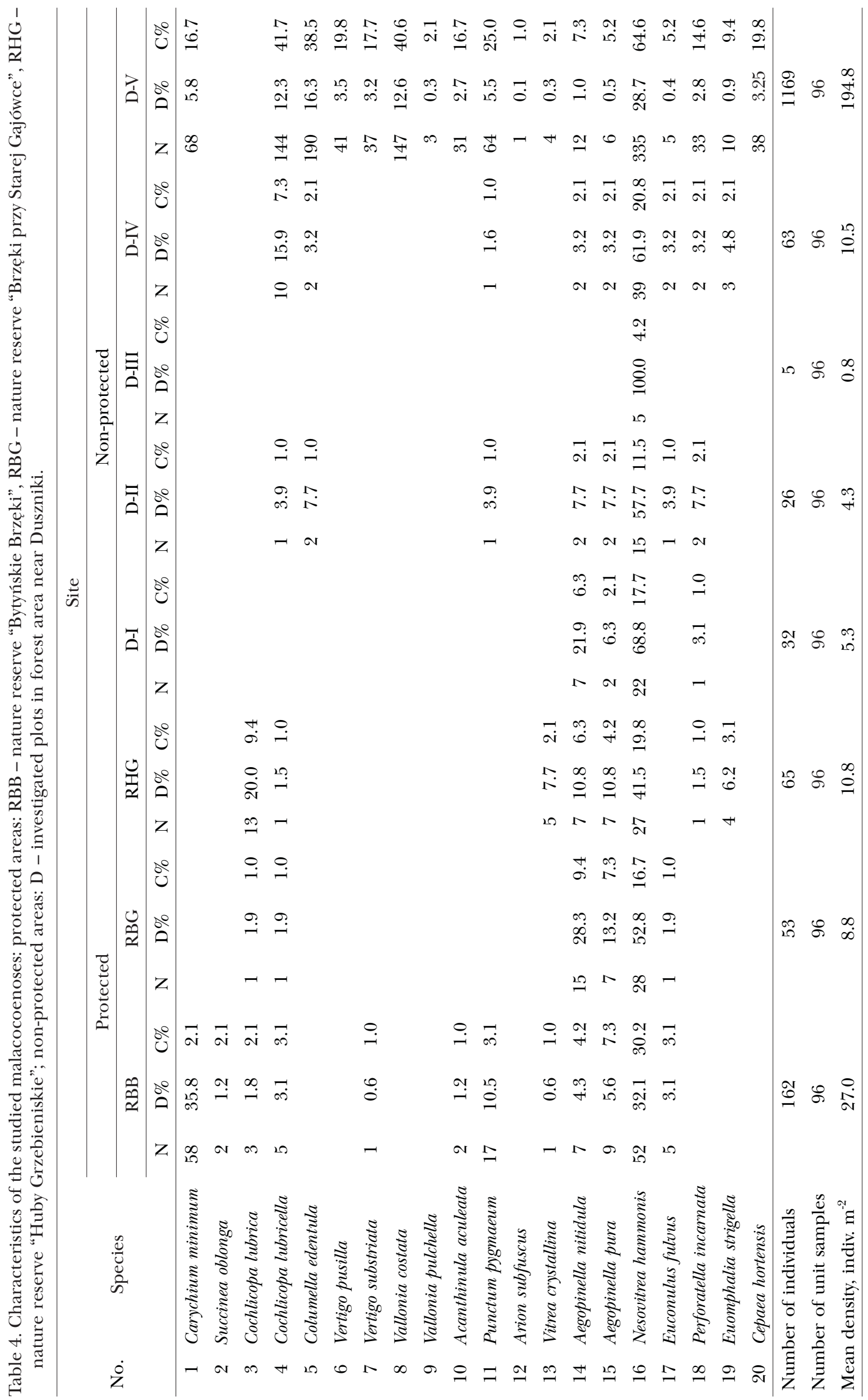


The mean density of snails in the nature reserves was 16 indiv. $\mathrm{m}^{-2}$, and in the non-protected areas 43 indiv. $\mathrm{m}^{-2}$. The only species with a maximum density per sample higher in the nature reserves than in the remaining plots was Carychium minimum (Table 4).

\section{DIVERSITY OF THE MALACOCOENOSES IN OLD AND LESS TRANSFORMED TREE STANDS}

Five plots with old tree stands and undergoing less anthropopressure were selected for quantitative analysis. Three were located in the nature reserves, two within managed forests near Duszniki. Basic characteristics of their malacocoenoses is given in Table 5 .

The nature reserve "Bytyńskie Brzęki" was the richest in species ( $60 \%$ total species), the lowest richness was observed in the old oak-hornbeam part (D-I) of the forest complex near Duszniki $(20 \%)$. In all the areas the most frequently found species was $N$. hammonis. The dominance structure was diverse, though mostly the dominant species were N. hammonis, A. nitidula and A. pura .

The average density in the studied plots was in direct proportion to the number of species (Fig. 5).

Table 5. Structure of the malacocoenoses of old forest stands: RBB - nature reserve "Bytyńskie Brzęki"; RBG - nature reserve "Brzęki przy Starej Gajówce"; RHG - nature reserve "Huby Grzebieniskie"; D - investigated plots in Duszniki forest complex; H' - Shannon-Weaver species diversity index; N (\%) - percentage of total species recorded based on 96 unit samples from each plot

\begin{tabular}{|c|c|c|c|}
\hline Plot H' & $\mathrm{N}(\%)$ & The most abundant species & The most frequent species \\
\hline $\begin{array}{c}\mathrm{RBB} \\
\mathrm{H}^{\prime}=1.725\end{array}$ & 60 & $\begin{array}{l}\text { Carychium minimum }-35.8 \% \\
\text { Nesovitrea hammonis }-32.1 \% \\
\text { Punctum pygmaeum }-10.5 \%\end{array}$ & $\begin{array}{l}\text { Nesovitrea hammonis }-30.2 \% \\
\text { Aegopinella pura }-7.3 \% \\
\text { Aegopinella nitidula }-4.2 \%\end{array}$ \\
\hline $\begin{array}{c}\text { RBG } \\
\mathrm{H}^{\prime}=1.186\end{array}$ & 30 & $\begin{array}{l}\text { Nesovitrea hammonis }-52.8 \% \\
\text { Aegopinella nitidula }-28.3 \% \% \\
\text { Aegopinella pura }-13.2 \%\end{array}$ & $\begin{array}{l}\text { Nesovitrea hammonis }-16.7 \% \\
\text { Aegopinella nitidula }-9.4 \% \\
\text { Aegopinella pura }-7.3 \%\end{array}$ \\
\hline $\begin{array}{c}\text { RHG } \\
H^{\prime}=1.664\end{array}$ & 40 & $\begin{array}{l}\text { Nesovitrea hammonis }-41.5 \% \\
\text { Cochlicopa lubrica }-20.0 \% \\
\text { Aegopinella pura }-10.8 \%\end{array}$ & $\begin{array}{l}\text { Nesovitrea hammonis }-19.8 \% \\
\text { Cochlicopa lubrica }-9.4 \% \\
\text { Aegopinella nitidula }-6.3 \%\end{array}$ \\
\hline $\begin{array}{c}\text { D-I } \\
\mathrm{H}^{\prime}=0.872\end{array}$ & 20 & $\begin{array}{l}\text { Nesovitrea hammonis }-68.8 \% \\
\text { Aegopinella nitidula }-21.9 \% \\
\text { Aegopinella pura }-6.3 \%\end{array}$ & $\begin{array}{l}\text { Nesovitrea hammonis }-17.7 \% \\
\text { Aegopinella nitidula }-6.3 \% \\
\text { Aegopinella pura }-2.1 \%\end{array}$ \\
\hline $\begin{array}{c}\text { D-II } \\
H^{\prime}=1.482\end{array}$ & 40 & $\begin{array}{l}\text { Nesovitrea hammonis }-57.7 \% \\
\text { Perforatella incarnata }-7.7 \% \\
\text { Aegopinella nitidula }-7.7 \% \\
\text { Aegopinella pura }-7.7 \% \\
\text { Columella edentula }-7.7 \%\end{array}$ & $\begin{array}{l}\text { Nesovitrea hammonis }-11.5 \% \\
\text { Perforatella incarnata }-2.1 \% \\
\text { Aegopinella nitidula }-2.1 \% \\
\text { Aegopinella pura }-2.1 \%\end{array}$ \\
\hline
\end{tabular}

A

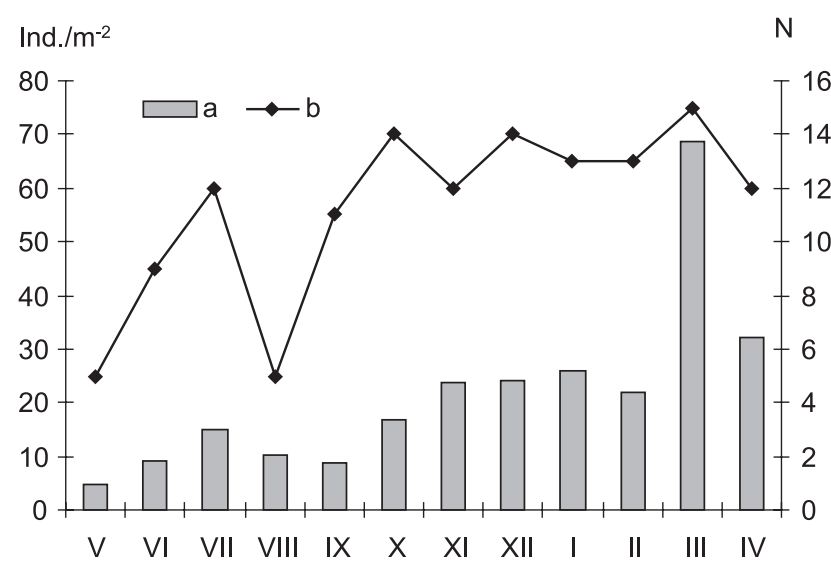

B

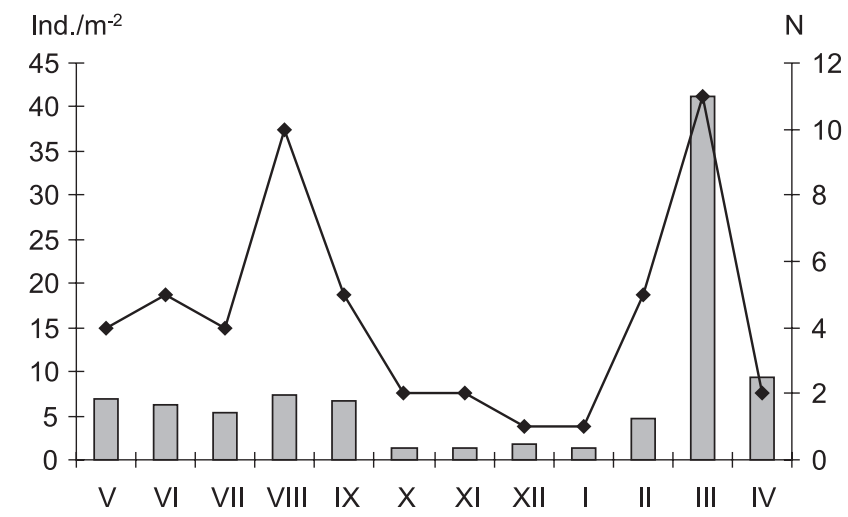

Fig. 5. Mean density and the number of species (b) in consecutive months in 2003-2004 in old forests stands of different protection status: A - not protected legally; B - located within nature reserves 
THE EFFECT OF ANTHROPOGENIC TRANSFORMATIONS OF TREE STANDS ON THE DIVERSITY OF MALACOCOENOSES

In order to trace the effect of tree stand transformations on the species composition and abundance of malacocoenoses, five plots from the forest complex near Duszniki were compared. Two (D-I and D-II) with old tree stands were reference plots, the remaining three (D-III, D-IV and D-V) represented various degree of regeneration of clear-felled areas.

Table 4 presents species composition and structure of malacocoenoses of individual plots. Contrary to what could be expected, the oldest tree stand (D-I) was not the richest; it harboured only four species, with a low mean density of 5.3 indiv. $\mathrm{m}^{-2}$. Plot D-II with an old tree stand and admixture of larch proved to be

\section{DISCUSSION}

An important question is if the local snail populations occurring at present in the studied plots can be regarded as components of the formerly existing malacocoenoses. The studied forests were originally parts of a continuous complex, later divided by fields and meadows. It can be supposed that the original malacocoenosis included all the species recorded in our studies, and the differences in the species composition and structure between the plots result mainly from anthropogenic changes. On the other hand, only the malacocoenosis with natural regeneration of ash on a clear-felling near Duszniki included $90 \%$ of all species recorded from the studied forests. All the plots located in old deciduous tree stands harbour much poorer malacocoenoses, with usually 20-60\% all species.

Besides the species composition, structure and age of tree stands, such factors as type and degree of coverage of herb layer, kind of litter and soil and humidity of the substratum are among main factors affecting forest malacocoenoses. The main components of deciduous forest malacocoenoses in western Wielkopolska are N. hammonis, Ae. nitidula, Ae. pura, P. pyg- richer, with eight species, but an even lower density of 4.3 indiv. $\mathrm{m}^{-2}$. Plot D-III, with its oak-hornbeam forest aged 60 years, was the poorest. Only one species, with the average density of 0.8 indiv. $\mathrm{m}^{-2}$, was found there.

In the remaining two plots (unsuccessful oak plantations of ca. 20 years), as a result of natural succession, the vegetation was different resulting in malacocoenoses of different species composition and structure. Plot D-IV (hazel shrubs and birch) harboured nine species, the mean density being 10.5 indiv. $\mathrm{m}^{-2}$. Plot D-V (ash-elm riverine forest with natural regeneration of ash) proved to be the richest. The number of recorded species was 18 (90\% all species). The mean density was nearly 20 times as high as in the remaining plots; the species diversity index $\left(\mathrm{H}^{\prime}\right)$ was also higher and amounted to 2.23.

maeum, C. lubricella, P. incarnata and C. minimum. The dominance structure of local snail communities is to a considerable degree dependent on habitat conditions, and these in turn may be modified as a result of human cativities. Clear-felling, practiced till not long ago, has led to drastic changes in the environment; the plots near Duszniki provide an example. Natural succession in clear-felled areas within a relatively short time (ca. 20 years) resulted in formation of plant communities different from the original ones, and to physico-chemical changes in the soil. This is reflected in the composition and structure of the malacocoenoses. Despite the very short distance separating them, the malacocoenoses differ considerably betwen the plots, suggesting an existence of ecological barriers precluding free dispersal within the whole forest complex.

Terrestrial snails studied by us (contrary to the soil fauna!) showed no preference for old oak-hornbeam stands. It may suggest that, under strong anthropopressure and in much transformed habitats, snails are capable of maintaining a high species diversity.

Dębiniec near Poznań (Poland). Malak. Abh. 15: 173-181.

KORALEWSKA-BATURA E. 1989. Ślimaki (Gastropoda) wybranego lasu grądowego Wielkopolski na przykładzie rezerwatu Jakubowo. Fragm. Faun. 32: 445-456.

KORALEWSKA-BATURA E. 1992. Mięczaki (Mollusca) Wielkopolski. Series Zoology 18, 41 pp., Wyd. Nauk. UAM, Poznań.

JANKOWIAK D., BŁOSZYK J., JACKIEWICZ M. 1991. Variation in malacofauna associations in relation to the type of plant community and habitat humidity in the natural reserve 
KORALEWSKA-BATURA E. 1993a. Slimaki (Gastropoda) siedlisk grądowych pod Opalenicą (woj. poznańskie). Bad. Fizjogr. Pol. Zach., Poznań, C 39: 49-63.

KORALEWSKA-BATURA E. 1993b. Ladowa fauna mięczaków (Mollusca) Wielkopolski. Bad. Fizjogr. Pol. Zach., Poznań, C 40: 5-13.
MARCZEWSKI E., STEINHAUS H. 1959. O odległości systematycznej biotopów. Zastosowania Matematyki 6: 195-203. WikTOR A. 2004. Ślimaki lądowe Polski. Mantis, Olsztyn.

Received: September 15th, 2005

Accepted: November 29th, 2005 